\title{
WEIGHTED PRODUCT (WP) UNTUK MEMBANGUN MESIN PENCARI DATA LULUSAN PERGURUAN TINGGI BERDASARKAN KEBUTUHAN PENGGUNA LULUSAN
}

\author{
Agung Budi Prasetyo \\ Teknik Informatika \\ STMIK AKAKOM Yogyakarta \\ Email: agung_bp@akakom.ac.id
}

\begin{abstract}
ABSTRAK
Telah menjadi tugas perguruan tinggi untuk membuat lulusan terserap dunia kerja. Keterserapan lulusan di dunia kerja akan tinggi apabila perguruan tinggi dapat melakukan link \& match antara kebutuhan perusahaan dengan kompetensi yang dimiliki lulusan. Link \& match yang baik dapat terjadi jika didukung oleh ketersediaan data yang akurat dan pengolah data yang baik. Untuk keperluan tersebut telah dibangun suatu purwarupa mesin pencari data lulusan perguruan tinggi berbasis web menggunakan algoritma SPK AHP. Kesulitan yang dihadapi adalah tidak mudahnya menyusun kriteria dalam jumlah banyak ke dalam skala prioritas berwujud pairwise comparisons matrix. Penelitian ini mengupayakan perbaikan atas penelitian sebelumnya dengan melakukan substitusi metode menggunakan metode Weighted Product (WP) yang bertujuan mempermudah beban pencari lulusan (pengambil keputusan) di mana pembobotan alternatif (rating kecocokan) dilakukan sendiri oleh mahasiswa calon lulusan sebagai calon alternatif. Pembobotan preferensi dilakukan dalam skala likert 1 sampai 5 oleh pihak pencari lulusan, demikian pula untuk pembobotan rating kecocokan yang dilakukan oleh mahasiswa calon lulusan. Sebagai luaran, aplikasi mesin pencari akan menampilkan data lulusan yang sesuai dengan kriteria yang kemudian dapat dgunakan pihak pencari kerja untuk dilanjutkan ke proses rekrutmen. Dengan 13 kriteria dan 55 sub kriteria yang tersedia pencari lulusan dapat menemukan sendiri lulusan sesuai dengan kriteria yang dikehendakinya.
\end{abstract}

Kata kunci: mesin pencari, data lulusan, weighted product.

\section{ABSTRACT}

University have a responsibility to make graduates absorbed by world of work. Absorption of graduates would be higher if university can link and match the competencies required by the workforce seeker with the competencies of graduates. Link \& match can be happened if it is supported by accurate data and good data processing. For this purpose, it has created a graduates data web-based search engine prototype using AHP DSS algorithms. The difficulties encountered are not easy to arrange many criteria into the scale of priorities in the form of a pairwise comparisons matrix. This study sought to improve on previous research by substitution method using Weighted Product (WP) which aims to ease workforce seeker as the decision makers where the weighting of alternative set by graduates as an alternative candidate. Weighting preference done in a 1 to 5 likert scale by workforce seeker, likewise for rating the suitability weighting, which is done by graduates. As an outcome, the search engine application will display the graduates data who fit the criteria, to be used by workforce seeker in the recruitment process. With 13 criteria and 55 sub-criteria are provided, workforce seekers themselves may find graduates that are required, in accordance with criteria that pleases.

Keywords: search engine, graduates data, weighted product..

\section{PENDAHULUAN}

Kebutuhan terhadap data dan informasi yang mutakhir, terbaharui, dan sinambung mengenai hubungan antara dunia pendidikan tinggi dan dunia kerja menjadi hal yang penting dan mendesak [1]. Kendala yang dihadapi adalah belum banyak tersedianya tools yang dapat membantu pengguna lulusan menemukan lulusan yang tepat sesuai kriteria dibutuhkan. Solusi atas masalah tersebut adalah perlunya diciptakan alat bantu pencarian data lulusan yang dapat memudahkan pihak pengguna lulusan menemukan data lulusan yang cocok dengan kriteria yang ditetapkan pengguna lulusan. Pada penelitian sebelumnya telah dibangun suatu aplikasi mesin pencari data lulusan menggunakan metode Analytical Hierarchy Process (AHP) sebagai metode SPKnya sebagaimana telah dipublikasikan dalam jurnal Simetris tahun 2016 [2]. Kesulitan yang dihadapi terletak pada implementasi metode itu sendiri di mana AHP selalu membutuhkan penyusunan pairwise comparisons matrix oleh pengambil keputusan. Dalam implementasinya penyusunan matriks tersebut masih mudah dilakukan terhadap 14 kriteria yang ada, namun cukup sulit untuk dilakukan terhadap 194 alternatif yang dikelolanya. 
Penelitian ini mencoba menawarkan teknik penyelesaian masalah yang berbeda dengan mengimplementasikan metode Weighted Product (WP) dalam aplikasi mesin pencari data lulusan. Metode WP merupakan metode penyelesaian masalah Multi Atribut Decision Making (MADM) yang menggunakan konsep perkalian terbobot [3]. Bobot yang diperlukan adalah bobot skala likert $1-5$ yang diberikan oleh pihak pengambil keputusan (pengguna lulusan) maupun pihak lulusan sebagai calon alternatif keputusan. Dengan penerapan metode ini beban pekerjaan pengambil keputusan menjadi lebih ringan karena pekerjaan pengelolaan alternatif dilakukan oleh mahasiswa calon lulusan itu sendiri. Mahasiswa calon lulusan diminta untuk memasukkan sendiri nilai-nilai tingkat kecocokan alternatif terhadap semua kriteria melalui form yang telah disediakan.

\section{METODOLOGI PENELITIAN}

Penelitian dilakukan dengan metodologi sebagai berikut: (1) kajian algoritma WP (2) desain dan pembuatan aplikasi (3) pengujian aplikasi.

\subsection{Algoritma WP}

Weighted Product (WP) adalah sebuah metode SPK yang digunakan untuk menyelesaikan masalah-masalah MADM (Multi Atribut Decision Making) [3]. Metode WP menggunakan perkalian untuk menghubungkan rating atribut, di mana rating setiap atribut harus dipangkatkan dulu dengan bobot atribut yang bersangkutan. Proses ini sama halnya dengan proses normalisasi. Langkah-langkah kerja AHP dipaparkan sebagai berikut.

1) Menentukan kriteria, sub kriteria dan alternatif keputusan

2) Pengambil keputusan memberikan bobot preferensi atau tingkat kepentingan setiap kriteria

$\mathrm{W}=\left(\mathrm{w}_{1}, \mathrm{w}_{2}, \mathrm{w}_{3}, \mathrm{w}_{4}, \ldots, \mathrm{w}_{\mathrm{j}}\right)$ dimana $\mathrm{j}=$ banyak kriteria

Perbaikan bobot preferensi dapat dilakukan dengan cara :

$W_{j}=\frac{W_{l}}{2 W_{j}}$ sedemikian sehingga Total Bobot $\Sigma W_{j}=1$

3) Menyusun Rating Kecocokan setiap alternatif atas setiap Kriteria dalam tabel rating kecocokan

Tabel 1. Rating kecocokan

\begin{tabular}{cccccc}
\hline \multirow{2}{*}{ Alternatif } & $\boldsymbol{5}$ Kriteria & $\boldsymbol{C} 2$ & $\boldsymbol{C} 3$ & $\boldsymbol{C 4}$ & $\boldsymbol{C}_{\boldsymbol{i}}$ \\
\hline $\mathrm{A} 1$ & $\left(x_{11}\right)$ & $\left(x_{12}\right)$ & $\left(x_{13}\right)$ & $\left(x_{14}\right)$ & $\left(x_{1 i}\right)$ \\
$\mathrm{A} 2$ & $\left(x_{21}\right)$ & $\left(x_{22}\right)$ & $\left(x_{23}\right)$ & $\left(x_{24}\right)$ & $\left(x_{2 i}\right)$ \\
$\mathrm{A} 3$ & $\left(x_{31}\right)$ & $\left(x_{32}\right)$ & $\left(x_{33}\right)$ & $\left(x_{34}\right)$ & $\left(x_{3 i}\right)$ \\
$\mathrm{A}_{\mathrm{i}}$ & $\left(x_{i 1}\right)$ & $\left(x_{i 2}\right)$ & $\left(x_{i 3}\right)$ & $\left(x_{i 4}\right)$ & $\left(x_{i j}\right)$ \\
\hline
\end{tabular}

di mana $\mathrm{x}_{\mathrm{ij}}$ berupa skala likert 1 sampai 5 yaitu $5=$ sangat baik (sangat cocok); $4=$ baik (cocok); $3=$ cukup; $2=$ buruk, (tidak cocok); 1 = sangat buruk (sangat tidak cocok)

4) Menyusun tabel rating kecocokan menjadi Matriks Keputusan(X)

\begin{tabular}{|lllll|}
\hline$\left(\mathrm{x}_{11}\right)$ & $\left(\mathrm{x}_{12}\right)$ & $\left(\mathrm{x}_{13}\right)$ & $\left(\mathrm{x}_{14}\right)$ & $\left(\mathrm{x}_{1 \mathrm{i}}\right)$ \\
$\left(\mathrm{x}_{21}\right)$ & $\left(\mathrm{x}_{22}\right)$ & $\left(\mathrm{x}_{23}\right)$ & $\left(\mathrm{x}_{24}\right)$ & $\left(\mathrm{x}_{2 \mathrm{i}}\right)$ \\
$\left(\mathrm{x}_{31}\right)$ & $\left(\mathrm{x}_{32}\right)$ & $\left(\mathrm{x}_{33}\right)$ & $\left(\mathrm{x}_{34}\right)$ & $\left(\mathrm{x}_{3 \mathrm{i}}\right)$ \\
$\left(\mathrm{x}_{\mathrm{i} 1}\right)$ & $\left(\mathrm{x}_{\mathrm{i} 2}\right)$ & $\left(\mathrm{x}_{\mathrm{i} 3}\right)$ & $\left(\mathrm{x}_{\mathrm{i} 4}\right)$ & $\left(\mathrm{x}_{\mathrm{ii}}\right)$ \\
\hline
\end{tabular}

5) Menghitung Vektor $\mathrm{S}$

$S_{t} \bullet \prod_{j=1} x_{t i}^{n i t}$ dengan $\mathrm{i}=1,2,3, \ldots, \mathrm{m}$.

di mana $\mathrm{w}_{\mathrm{i}}$ adalah pangkat bernilai positif untuk atribut keuntungan, dan bernilai negatif untuk atribut biaya

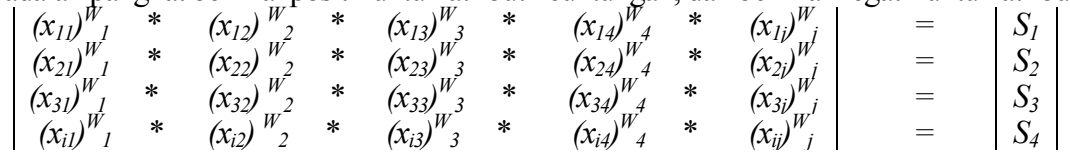

6) Proses Perankingan dilakukan dengan cara menentukan nilai vektor $V_{i}$ dengan rumus

$$
V_{t}-\frac{5}{2 \eta+1}
$$


Preferensi relatif dari setiap alternatif $\left(\mathrm{V}_{\mathrm{i}}\right)$ yang lebih besar mengindikasikan alternatif $\mathrm{A}_{\mathrm{i}}$ terpilih

$$
\begin{array}{lll}
\mathrm{V}_{1}=\left(\mathrm{S}_{1}\right) & / & \left(\mathrm{S}_{1}\right)+\left(\mathrm{S}_{2}\right)+\left(\mathrm{S}_{3}\right)+\left(\mathrm{S}_{4}\right)+\ldots .+\left(\mathrm{S}_{\mathrm{j}}\right) \\
\mathrm{V}_{2}=\left(\mathrm{S}_{2}\right) & / & \left(\mathrm{S}_{1}\right)+\left(\mathrm{S}_{2}\right)+\left(\mathrm{S}_{3}\right)+\left(\mathrm{S}_{4}\right)+\ldots .+\left(\mathrm{S}_{\mathrm{j}}\right) \\
\mathrm{V}_{3}=\left(\mathrm{S}_{1}\right) & / & \left(\mathrm{S}_{1}\right)+\left(\mathrm{S}_{2}\right)+\left(\mathrm{S}_{3}\right)+\left(\mathrm{S}_{4}\right)+\ldots .+\left(\mathrm{S}_{\mathrm{j}}\right) \\
\ldots & =\ldots & \\
\mathrm{V}_{\mathrm{j}}=\left(\mathrm{S}_{\mathrm{j}}\right) & / & \left(\mathrm{S}_{1}\right)+\left(\mathrm{S}_{2}\right)+\left(\mathrm{S}_{3}\right)+\left(\mathrm{S}_{4}\right)+\ldots .+\left(\mathrm{S}_{\mathrm{j}}\right)
\end{array}
$$

7) Proses Perankingan kedua dilakukan dengan cara mengurutkan alternatif berdasarkan nilai $V_{i}$ secara urut Turun mulai $\mathrm{V}_{\mathrm{i}}$ yang paling besar.

8) Selesai

\subsection{Desain Dan Pembuatan Aplikasi}

Proses pembuatan aplikasi mencakup 2 aspek yaitu : 1) pembuatan web dan 2) penerapan WP.

1) Sistem Berbasis Web

Aplikasi dibangun dalam prototipe web penggunakan bahasa PHP dan database MySQL [4]. Aplikasi mesin pencari tersebut didesain sesuai dengan Diagram Konteks sebagaimana tersaji dalam gambar 1. Dalam pembuatan web, aplikasi mesin pencari memiliki 2 entitas berbeda yaitu pengguna lulusan dan lulusan. Pengguna lulusan memberi masukan data berupa nilai tingkat kepentingan atau bobot preferensi (W) atas kriteria yang ada sedangkan mahasiswa calon lulusan memberikan masukan berupa nilai rating kecocokan (X) mereka terhadap setiap kriteria/ sub kriteria yang ada.

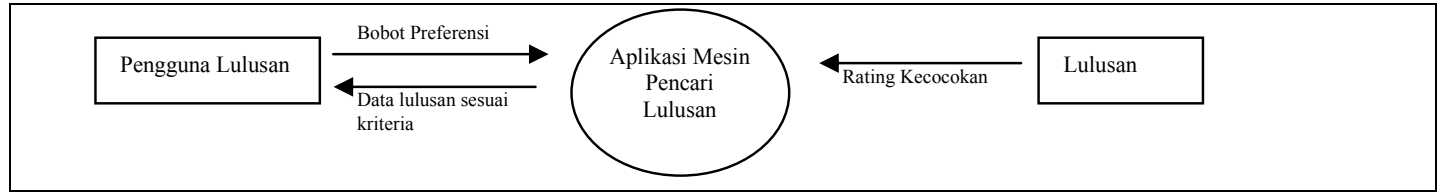

\section{Gambar 1. Diagram Konteks Aplikasi}

Gambar 2 memperlihatkan rangkaian proses-proses mulai dari data yang dimasukkan oleh pengguna lulusan maupun lulusan hingga diperolehnya hasil pencarian.

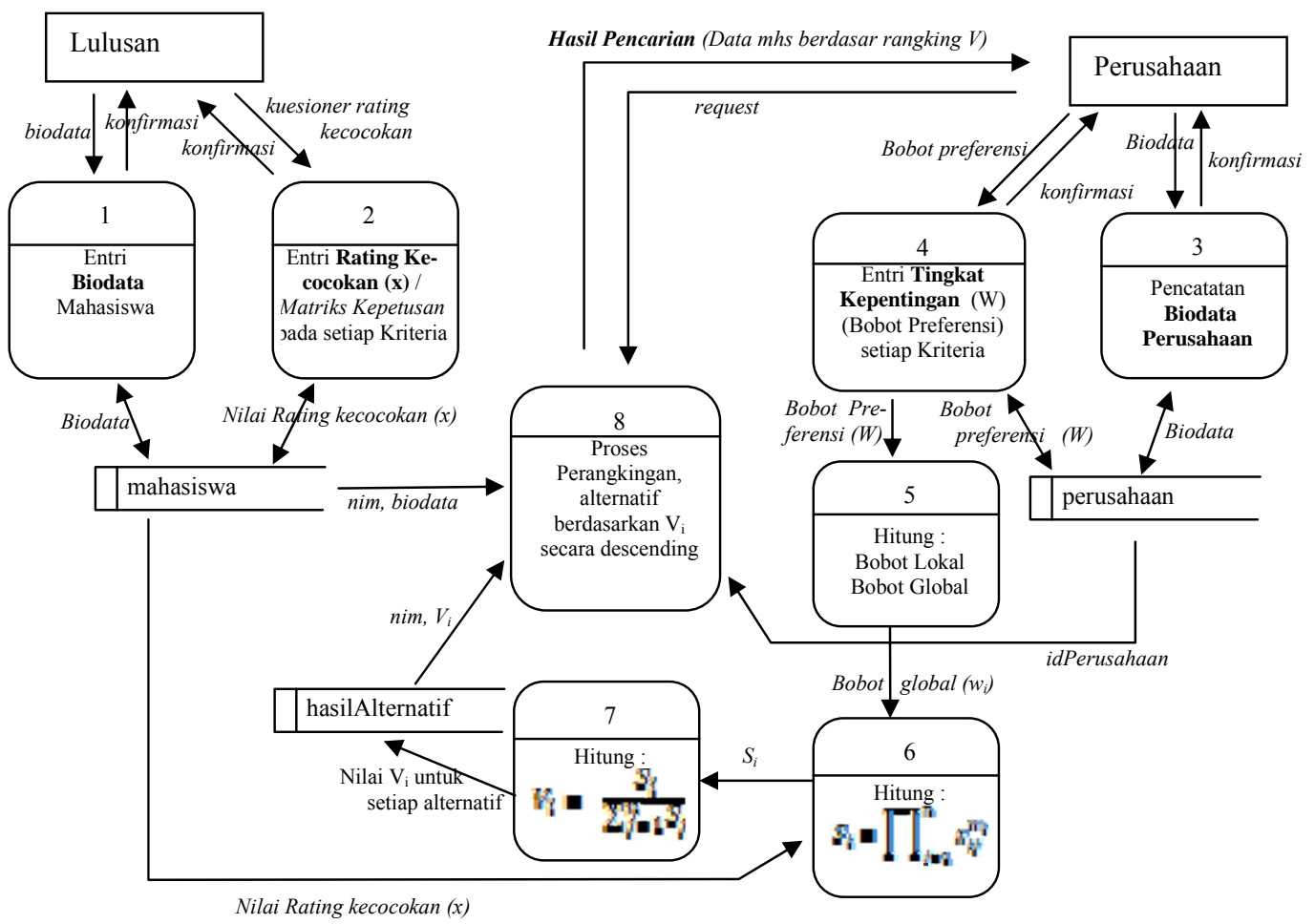

Gambar 2 DFD Level 1 
2) Penerapan Metode Penghitungan WP

Penerapan metode WP yang didasarkan pada langkah-langkah kerja WP dipaparkan proses kerjanya melalui sejumlah algoritma program sebagai berikut.

a. Langkah 1 : Menentukan kriteria dan subkriteria yang dibutuhkan perusahaan

Terdapat 13 kriteria yang sering dicari oleh pengguna lulusan di STMIK AKAKOM meliputi : (1) Menguasai Bahasa Pemrograman, (2) Menguasai Sistem Operasi, (3) Menguasai Program Aplikasi, (4) Memiliki Kompetensi tertentu di bidang IT, (5) menyukai bidang IT, (6) Rencana untuk berkarir di bidang tertentu (IT), (7) Bersedia direkrut kerja oleh perusahaan IT, (8) memiliki pengalaman kerja, (9) Memiliki pengalaman dalam tim, (10) memiliki pengalaman dalam proyek, (11) Memiliki sertifikasi tertentu, (12) Memiliki pengalaman bisnis dan (13) Menguasai bahasa asing tertentu.

Kriteria menguasai bahasa pemrograman memiliki 9 sub kriteria yaitu bahasa pemrograman Java (PMR1), bahasa pemrograman C/C++/C\# (PMR2), bahasa pemrograman Pascal/Delphi (PMR3), bahasa pemrograman Basic/ VB (PMR4), bahasa pemrograman PHP (PMR5), bahasa pemrograman Asp.net (PMR6), bahasa pemrograman Python/ Pearl (PMR7), bahasa pemrograman Prolog (PMR8), dan bahasa Asembler (PMR9).

Kriteria menguasai sistem operasi memiliki 6 sub kriteria yaitu sistem operasi Windows (SO1), sistem operasi Linux (SO2), sistem operasi Sun (SO3), sistem operasi Unix (SO4), sistem operasi Android (SO5), dan sistem operasi Windows Phone (SO6).

Kriteria menguasai program aplikasi memiliki 8 sub kriteria yaitu Aplikasi Perkantoran (Wordprocessing/ Spreadsheet/ Presentation/ d1l) (PA1), Aplikasi Grafis dan Desain (PA2), Aplikasi Multimedia (audio/ video) (PA3), Aplikasi Internet (Email/ Chat/ Browsing/ Map/ dll) (PA4), Aplikasi Mobile (Android/ Windows Phone/ dll) (PA5), Aplikasi Keamanan Jaringan (PA6), Aplikasi Database (MySQL/ Oracle/ Paradow/ dll) (PA7), Aplikasi Keuangan dan Akuntansi (PA8).

Kriteria menguasai kompetensi IT tertentu memiliki 14 sub kriteria yaitu Komunikasi Data dan Jaringan Komputer (KIT1), Keamanan Jaringan(KIT2), Sistem Kendali dan Robotika (KIT3), Programming (KIT4), Sistem Cerdas (KIT5), Komputasi Cloud (KIT6), Komputasi Mobile (KIT7), Web, Framework, GIS (KIT8), Data Warehouse dan Data Mining (KIT9), Basis Data dan Sistem Informasi (KIT10), Multimedia dan Pengolahan Citra (KIT11), Games (KIT12), Hardware, Instalasi dan Maintenance (KIT13), dan Komputer Akuntansi (KIT14).

Kriteria rencana untuk berkarir di bidang IT tertentu memiliki 11 sub kriteria yaitu sebagai Programmer (KR1), sebagai Sistem Analyst (KR2), sebagai Quality Assurance (KR3), sebagai Operator (KR4), sebagai Tester (KR5), sebagai Implementor (KR6), sebagai Operating Maintenance (KR7), sebagai Web Developer (KR8), sebagai Desain Grafis (KR9), sebagai IT Support (KR10), dan karir lainnya (KR11).

Kriteria menguasai bahasa asing memiliki 7 sub kriteria yaitu bahasa Inggris (BA1), bahasa Prancis (BA2), bahasa Portugues (BA3), bahasa Arab (BA4), bahasa Jepang (BA5), bahasa Mandarin (BA6), dan bahasa Korea (BA7).

b. Langkah 2 : Pemberian bobot preferensi atau tingkat kepentingan setiap kriteria oleh Pengambil keputusan

Bobot preferensi sebagaimana dirumuskan pada persamaan (1) diberikan dalam bentuk skala likert 1 sampai 5 di mana 1 = sangat tidak penting, $2=$ tidak penting, $3=$ cukup, $4=$ penting, dan $5=$ sangat penting (lihat gambar 3). Pemberian bobot preferensi setiap kriteria oleh pengambil keputusan ini digambarkan sebagai proses nomor 4 pada gambar 2.

Perbaikan bobot preferensi sebagaimana dirumuskan pada persamaan (2) dilakukan terhadap nilai W sedemikian sehingga Total Bobot $\mathbb{Z}_{j}=1$. Langkah pertama dari perbaikan bobot dilakukan dengan menghitung nilai bobot lokal yang dilakukan dengan script berikut.

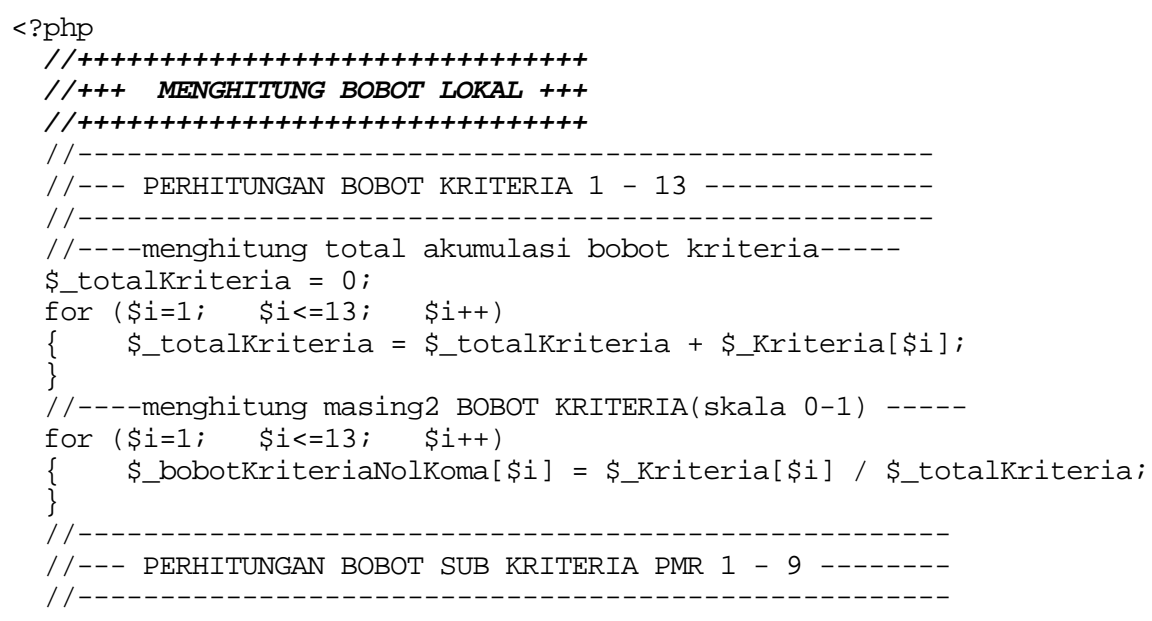


//----menghitung akumulasi bobot sub krit: Bahasa Pemrograman-\$_totalPMR $=0$; 
Setelah penghitungan nilai bobot lokal diperoleh kemudian dilakukan penghitungan nilai bobot global yang dilakukan dengan script berikut.

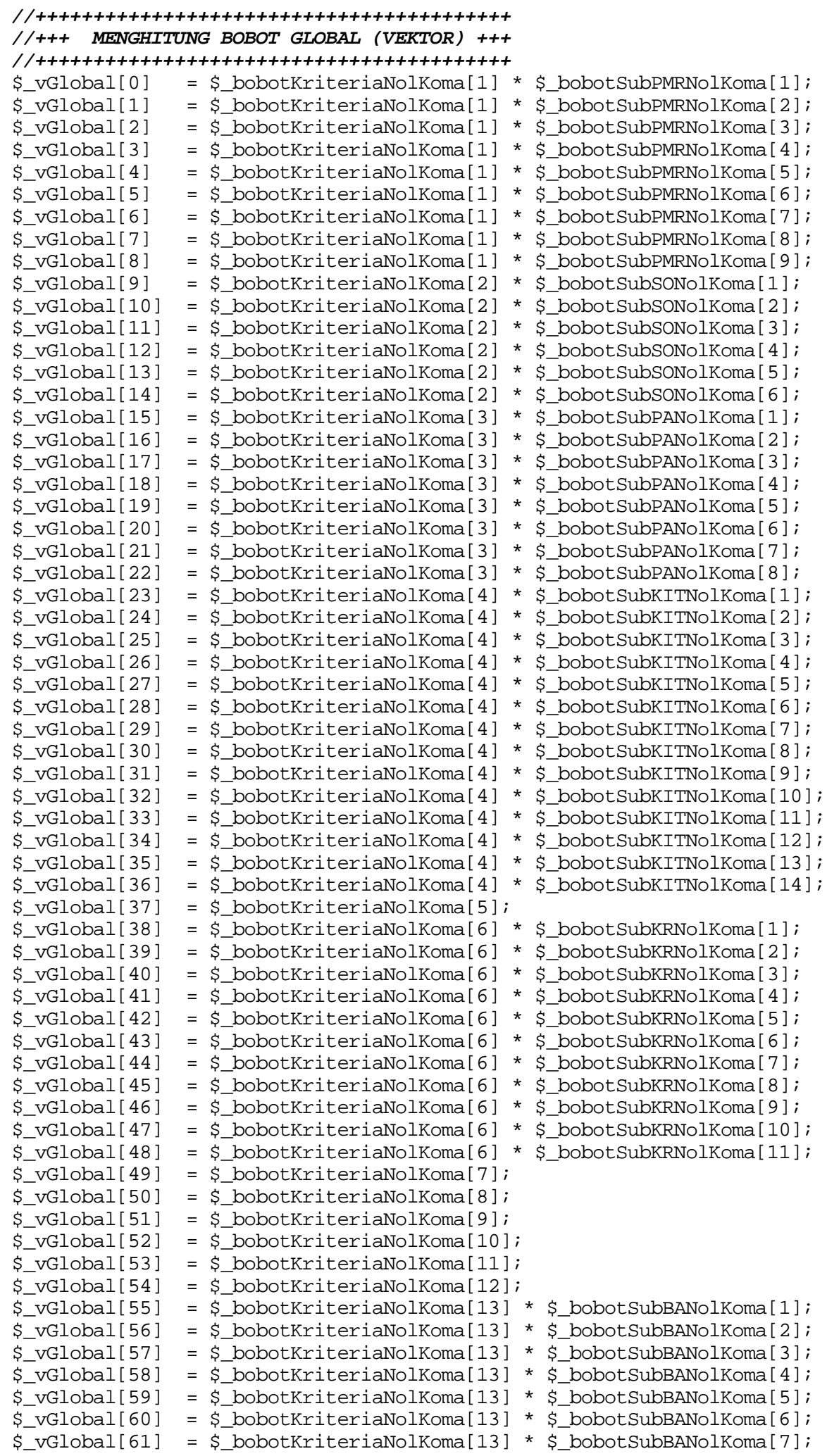


c. Langkah 3 : Pemberian Rating Kecocokan dari setiap alternatif pada setiap Kriteria oleh Lulusan Rating kecocokan dari setiap alternatif pada setiap kriteria diberikan oleh lulusan dalam bentuk skala likert 1 sampai 5 di mana 1 = sangat tidak menguasai (sangat tidak sesuai), 2 = tidak menguasai (tidak sesuai), $3=$ cukup, $4=$ menguasai (sesuai), dan $5=$ sangat menguasai (sangat sesuai) (lihat gambar 4 ).

d. Langkah 4 : Penyusunan tabel rating kecocokan menjadi Matriks Keputusan (X)

Proses penyusunan matriks $\mathrm{X}$ dilakukan dengan script berikut include "KoneksiKu.php";

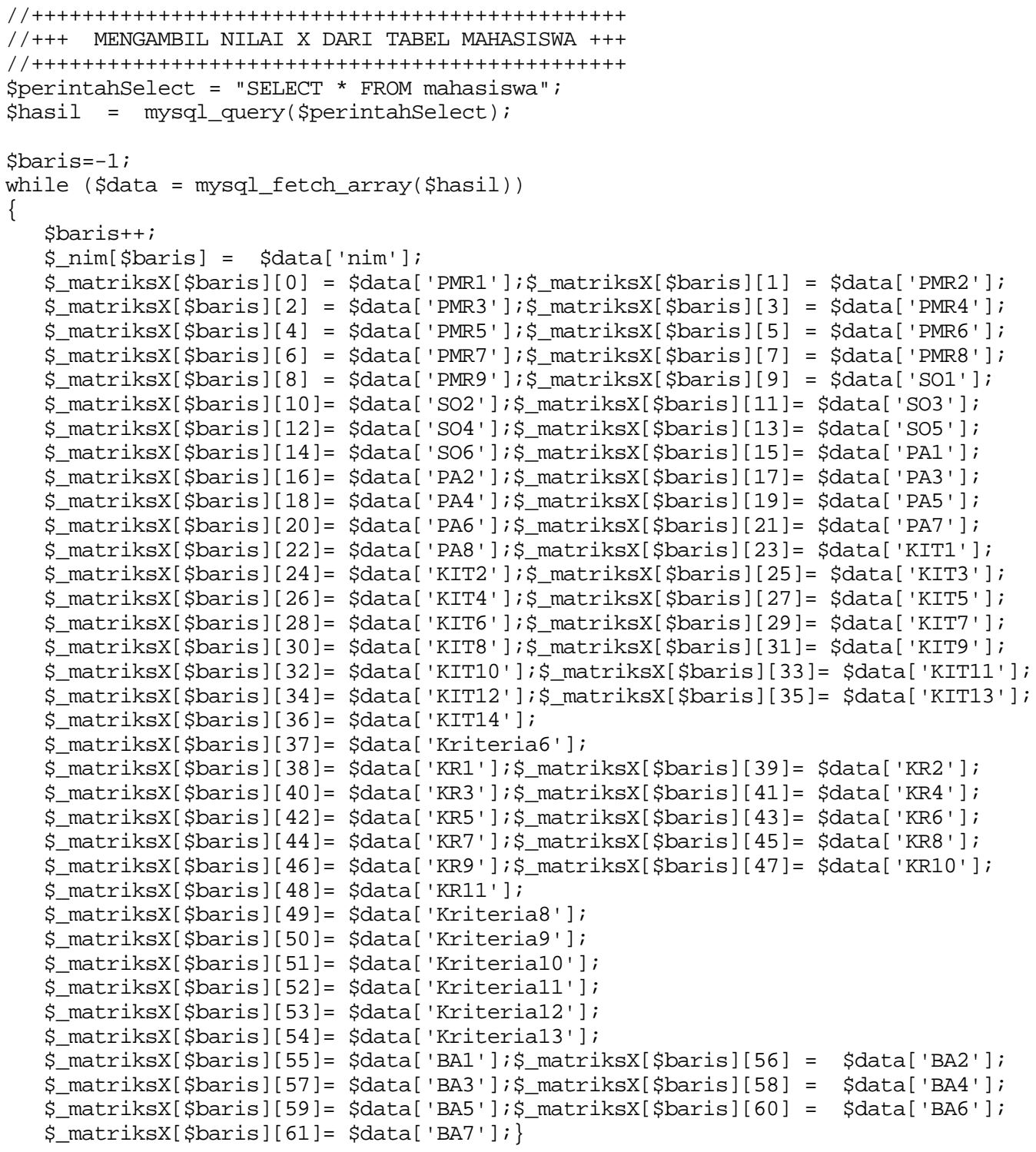

e. Langkah 5 : Menghitung Vektor S

Proses penghitungan vektor S dilakukan dengan persamaan (3). Menghitung vektor S sebagaimana digambarkan sebagai proses nomor 6 pada gambar 2. dan dilakukan dengan script berikut.

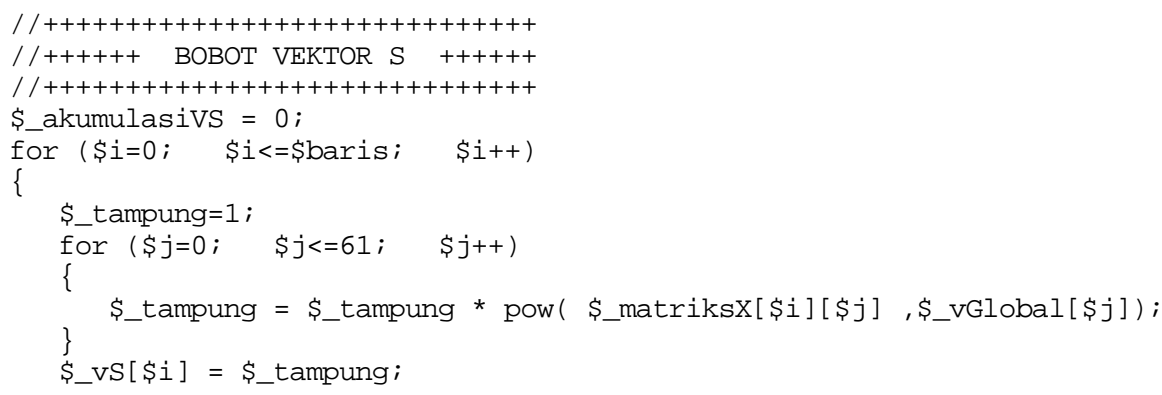


\$_akumulasivs = \$_akumulasivs + \$_vS[\$i];

f. Langkah 6 : Proses Perankingan Pertama dilakukan dengan cara menentukan nilai vektor V Proses Perankingan Pertama dilakukan dengan cara menentukan nilai vektor V dengan menggunakan persamaan (4). Proses penghitungan vektor $V_{i}$ sebagaimana digambarkan sebagai proses nomor 7 Gambar 2. dilakukan dengan script berikut.

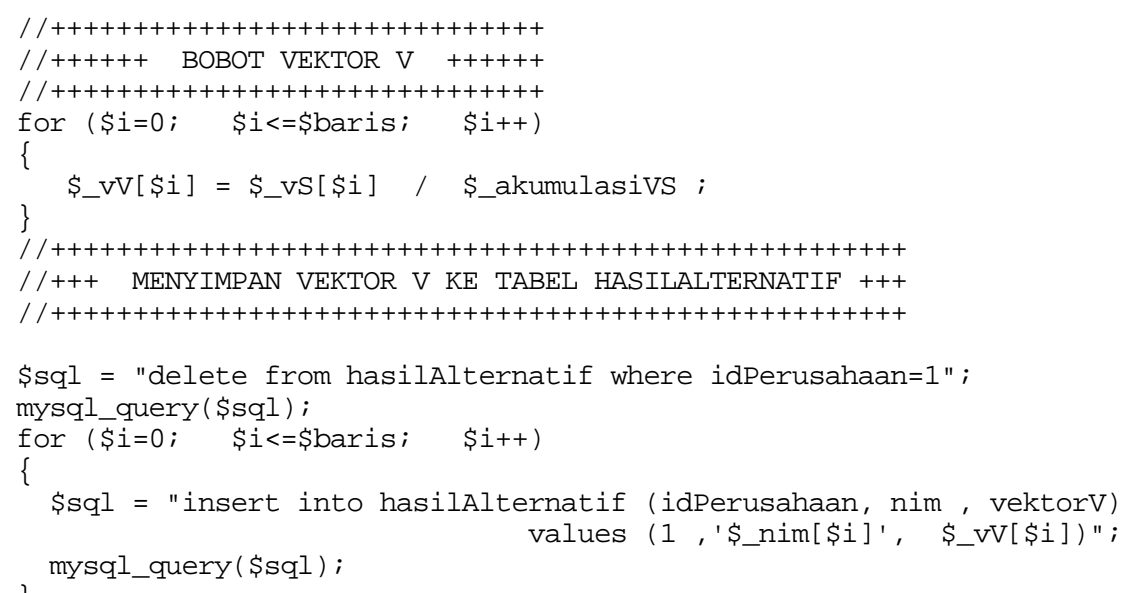

g. Langkah 7 : Proses Perankingan Kedua dengan mengurutkan alternatif berdasarkan nilai Vi

Proses Perankingan Kedua dengan mengurutkan alternatif berdasarkan nilai $\mathrm{V}_{\mathrm{i}}$ dilakukan dengan cara mengurutkan alternatif berdasarkan nilai $\mathrm{V}$ secara urut Turun mulai $\mathrm{V}$ yang paling besar. Proses penghitungan vektor $\mathrm{V}_{\mathrm{i}}$ digambarkan sebagai proses nomor 8 Gambar 2. dan dilakukan dengan script berikut

$<$ ?

include "KoneksiKu.php";

\$perintahselect $=$ "SELECT *

FROM 'hasilalternatif', 'mahasiswa`, 'perusahaan WHERE

hasilalternatif. nim=mahasiswa. nim

and

hasilalternatif.idPerusahaan

= perusahaan.idPerusahaan

?>

ORDER BY hasilalternatif.vektorV DESC";

\section{HASIL DAN PEMBAHASAN}

Pada bagian ini dilakukan untuk menguji akurasi kinerja aplikasi yang dibangun. Pengujian dilakukan dengan membandingkan hasil perhitungan aplikasi dengan hasil perhitungan yang dilakukan menggunakan aplikasi spreadsheet. Pengujian dilakukan menggunakan data yang mewakili 2 pihak berbeda sebagaimana dimaksud dalam diagram konteks (gambar 1)

Data pertama berasal dari pihak mahasiswa calon lulusan STMIK AKAKOM periode II 2014/2015 sebanyak 194 orang dari Akakom Career Center [5]. Data tersebut meliputi biodata dan informasi mengenai rating kecocokan terhadap kriteria (1) Bahasa pemrograman yang dikuasai, (2) sistem operasi yang dikuasai, (3) progam aplikasi yang dikuasai, (4) Kompetensi sebagai programmer, (5) Kesukaan pada bidang IT, (6) rencana berkarir di bidang IT, (7) kesediaan direkrut perusahaan IT, (8) pengalaman kerja, (9) pengalaman timwork, (10) pernah mengelola proyek, (11) sertifikasi, (12) pengalaman bisnis, (13) bahasa asing . Rating kecocokan diberikan oleh setiap lulusan dalam bentuk skala likert 1 sampai 5 di mana 1 berarti sangat tidak menguasai (sangat tidak sesuai), 2 berarti tidak menguasai (tidak sesuai), 3 berarti cukup, 4 berarti menguasai (sesuai), dan 5 berarti sangat menguasai (sangat sesuai)

Data kedua berasal dari pihak rekanan Akakom Career Center yaitu PT.Intersolusi Cipta Softindo sebagai pihak pengguna lulusan. Data tersebut berupa bobot preferensi atas kriteria dan sub kriteria dalam skala likert $1-5$ sebagaimana tersaji dalam Tabel 2 dan Tabel 3 (disajikan sekaligus beserta skala normalnya). Bobot 5 berarti kriteria memiliki nilai yang sangat penting, bobot 4 berarti penting, bobot 3 berarti cukup, bobot 2 berarti tidak penting, dan bobot 1 berarti sangat tidak penting. 
Tabel 2. Bobot preferensi atas kriteria

\begin{tabular}{llcc}
\hline \multirow{2}{*}{ No } & \multirow{2}{*}{ riteria } & \multicolumn{2}{c}{ Bobot Kriteria } \\
\cline { 3 - 4 } & Skala & Normal \\
\hline 1 & Bahasa Pemrograman yang dikuasai & $\mathbf{5}$ & 0.139 \\
2 & Sistem Operasi yang dikuasai & $\mathbf{2}$ & 0.056 \\
3 & Kompetensi dalam menggunakan Program Aplikasi & $\mathbf{3}$ & 0.083 \\
4 & Kompetensi BIDANG IT yang telah dimiliki & $\mathbf{4}$ & 0.111 \\
5 & Menyukai bidang IT & $\mathbf{3}$ & 0.083 \\
6 & Ada rencana berkarir di bidang IT & $\mathbf{4}$ & 0.111 \\
7 & Bersedia direkrut bekerja oleh Perusahaan IT & $\mathbf{4}$ & 0.111 \\
8 & Pengalaman Kerja selama menjadi mahasiswa & $\mathbf{2}$ & 0.056 \\
9 & Pengalaman dalam tim/ organisasi/ komunitas selama & $\mathbf{1}$ & 0.028 \\
10 & Pengalaman dalam mengelola proyek/ kegiatan/ & $\mathbf{1}$ & 0.028 \\
11 & Memiliki Sertifikasi misalnya: DAT, Oracle, CICSO, & $\mathbf{3}$ & 0.083 \\
12 & Pengalaman bisnis/ enterpreneur/ internet marketing & $\mathbf{1}$ & 0.028 \\
13 & Penguasaan Bahasa Asing & $\mathbf{3}$ & 0.083 \\
\hline
\end{tabular}

Tabel 3. Bobot preferensi atas sub kriteria

\begin{tabular}{|c|c|c|c|c|c|}
\hline \multirow{2}{*}{ No } & \multirow{2}{*}{ Kriteria } & \multirow{2}{*}{ Sub Kriteria } & \multicolumn{3}{|c|}{ Bobot Sub Kriteria } \\
\hline & & & Skala & Lokal & Global \\
\hline \multirow[t]{9}{*}{1} & Bahasa & (PMR1) Java & 5 & 0.185185 & 0.02572 \\
\hline & Pemrograman & $(\mathrm{PMR} 2) \mathrm{C} / \mathrm{C}++/ \mathrm{C} \#$ & 3 & 0.111111 & 0.015432 \\
\hline & yang dikuasai & (PMR3) Pascal/ Delphi & 3 & 0.111111 & 0.015432 \\
\hline & & (PMR4) Basic/VB & 2 & 0.074074 & 0.010288 \\
\hline & & (PMR5) Php & 5 & 0.185185 & 0.02572 \\
\hline & & (PMR6) Asp.net & 5 & 0.185185 & 0.02572 \\
\hline & & (PMR7) Python/ Pearl & 2 & 0.074074 & 0.010288 \\
\hline & & (PMR8) Prolog & 1 & 0.037037 & 0.005144 \\
\hline & & (PMR9) Asembler & 1 & 0.037037 & 0.005144 \\
\hline \multirow[t]{6}{*}{2} & Sistem & (SO1) Windows & 5 & 0.294118 & 0.01634 \\
\hline & Operasi yang & (SO2) Linux & 4 & 0.235294 & 0.013072 \\
\hline & dikuasai & (SO3) Sun & 2 & 0.117647 & 0.006536 \\
\hline & & (SO4) Unix & 2 & 0.117647 & 0.006536 \\
\hline & & (SO5) Android & 3 & 0.176471 & 0.009804 \\
\hline & & (SO6) Windows Phone & 1 & 0.058824 & 0.003268 \\
\hline \multirow[t]{8}{*}{3} & Kompetensi & (PA1) Aplikasi Perkantoran & 3 & 0.107143 & 0.008929 \\
\hline & dalam & (PA2) Aplikasi Grafis dan & 3 & 0.107143 & 0.008929 \\
\hline & menggunakan & (PA3) Aplikasi Multimedia & 4 & 0.142857 & 0.011905 \\
\hline & Program & (PA4) Aplikasi Internet & 4 & 0.142857 & 0.011905 \\
\hline & Aplikasi & (PA5) Aplikasi Mobile & 2 & 0.071429 & 0.005952 \\
\hline & Apпाкаsi & (PA6) Aplikasi Keamanan & $\overline{3}$ & 0.107143 & 0.008929 \\
\hline & & (PA7) Aplikasi Database & 5 & 0.178571 & 0.014881 \\
\hline & & (PA8) Aplikasi Keuangan & 4 & 0.142857 & 0.011905 \\
\hline \multirow[t]{14}{*}{4} & Kompetensi & (KIT1) Komunikasi Data & 4 & 0.095238 & 0.010582 \\
\hline & BIDANG IT & (KIT2) Keamanan Jaringan & 3 & 0.071429 & 0.007937 \\
\hline & yang telah & (KIT3) Sistem Kendali dan & 2 & 0.047619 & 0.005291 \\
\hline & dimiliki & (KIT4) Programming & 5 & 0.119048 & 0.013228 \\
\hline & & (KIT5) Sistem Cerdas & 4 & 0.095238 & 0.010582 \\
\hline & & (KIT6) Komputasi Cloud & 3 & 0.071429 & 0.007937 \\
\hline & & (KIT7) Komputasi Mobile & 3 & 0.071429 & 0.007937 \\
\hline & & (KIT8) Web, Framework, & 4 & 0.095238 & 0.010582 \\
\hline & & (KIT9) Data Warehouse dan & 2 & 0.047619 & 0.005291 \\
\hline & & (KIT10) Basis Data dan & 5 & 0.119048 & 0.013228 \\
\hline & & (KIT11) Multimedia dan & 2 & 0.047619 & 0.005291 \\
\hline & & (KIT12) Games & 1 & 0.02381 & 0.002646 \\
\hline & & (KIT13) Hardware, Instalasi & 2 & 0.047619 & 0.005291 \\
\hline & & (KIT14) Komputer & 2 & 0.047619 & 0.005291 \\
\hline 5 & Menyukai bida & ng IT & & & 0.083333 \\
\hline
\end{tabular}




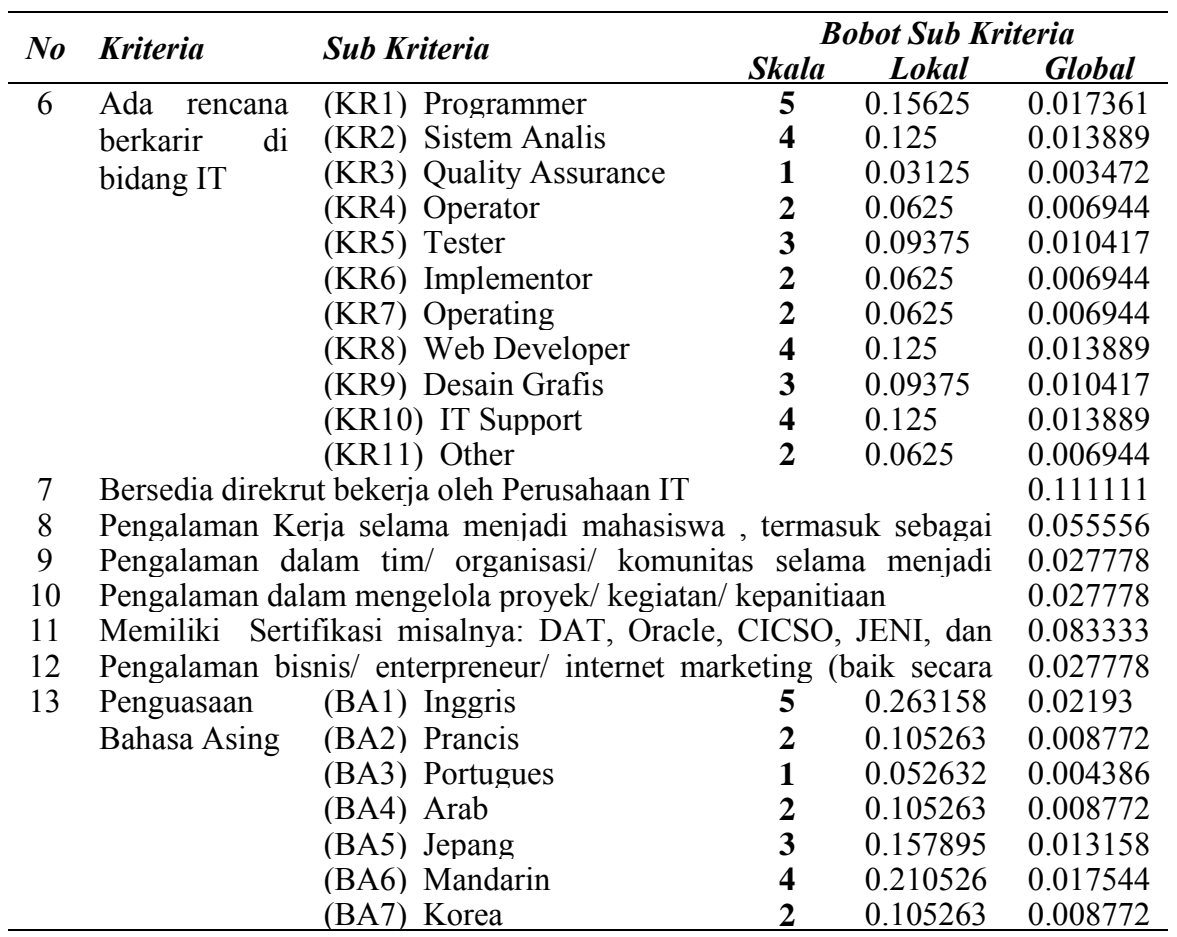

Pada aplikasi, bobot preferensi diberikan oleh pengguna lulusan untuk didokumentasi dalam basisdata melalui antar muka web yang ditunjukkan dalam gambar 3, sedangkan rating kecocokan dari setiap alternatif atas setiap kriteria diberikan oleh lulusan untuk didokumentasi melalui antar muka web yang ditunjukkan dalam gambar 4.

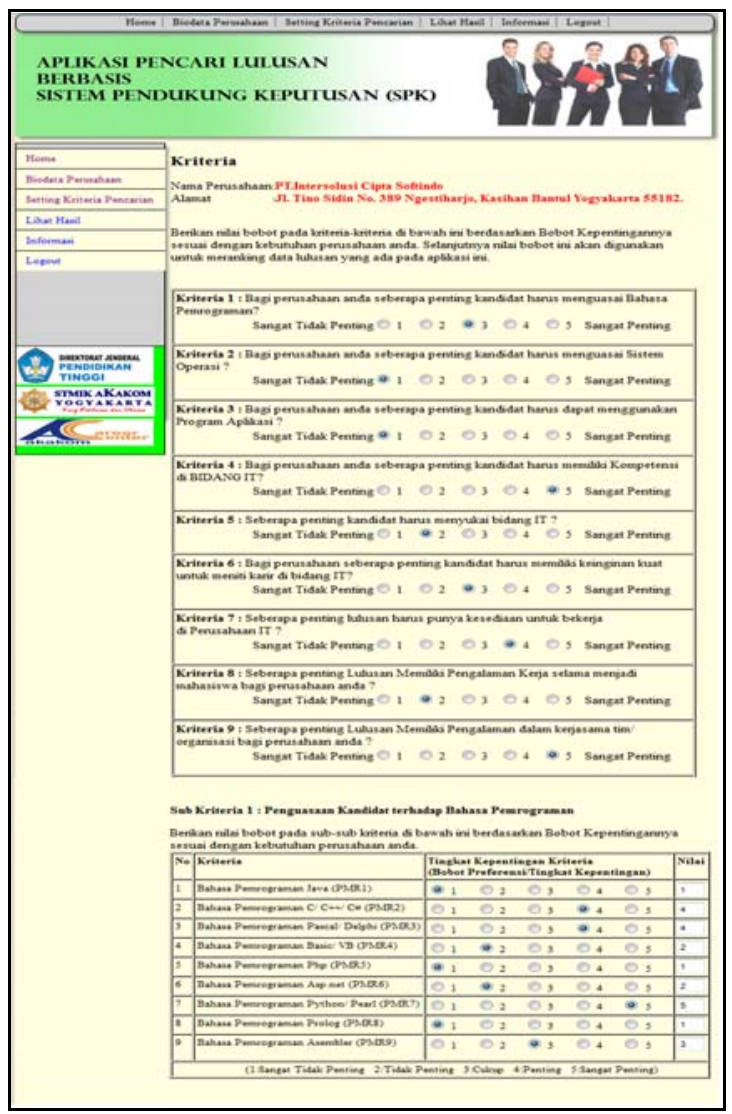

Gambar 3. Pemberian Bobot Preferensi Setiap Kriteria Oleh Pengguna Lulusan 
Home | Biodata | Kvesioner | Informasi $\mid$ Logout

\section{APLIKASI PENCARI LULUSAN \\ BERBASIS \\ SISTEM PENDUKUNG KEPUTUSAN (SPK)}

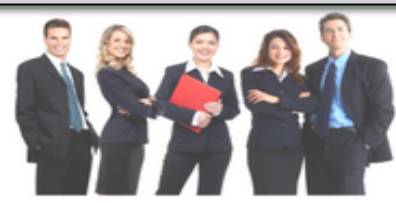

\begin{tabular}{|l|}
\hline Home \\
\hline Biodata \\
\hline Kvesioner \\
\hline Informasi \\
\hline Logout
\end{tabular}

Biodata

Nama Mahsuivw: Munemmed Nur Hideye

NM $\quad 113310019$

Silakan isi kuesioner di bawah ini.

Data kuesioner yang anda isi akan digunakan untuk menudahkan perusahaan dalam

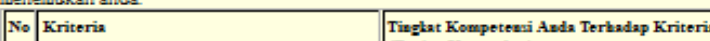

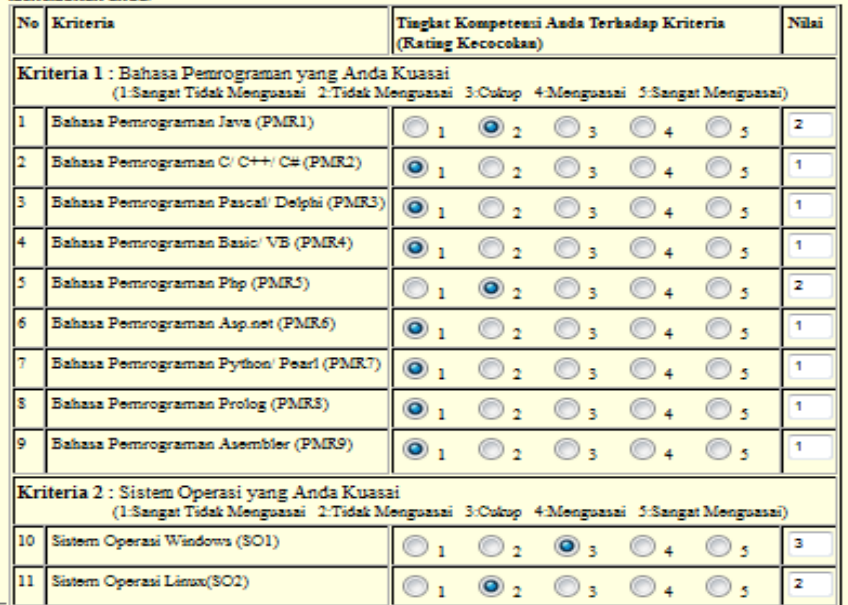

Gambar 4. Pemberian Rating Kecocokan dari Setiap Alternatif pada Setiap Kriteria Diberikan oleh Lulusan

Melalui proses perhitungan atas persamaan (3) dan (4) didapatkan hasil perhitungan Vektor S dan V sebagaimana tersaji pada tabel 4 .

Tabel 4. Hasil perhitungan vektor S dan V atas 194 alternatif antara aplikasi dan spreadsheet

\begin{tabular}{crccc}
\hline $\begin{array}{c}\text { Al- } \\
\text { ter- }\end{array}$ & No Mhs & $\begin{array}{c}\text { Hasil Perhitungan } \\
\text { Spreadsheet }\end{array}$ & $\begin{array}{c}\text { Hasil Perhitungan } \\
\text { Aplikasi }\end{array}$ \\
\cline { 3 - 5 } tif & & Vektor S & Vektor V & Vektor S Vektor V \\
\hline 1 & 9330010 & 1.5798960620 .0044469971 .579896 & 0.004447 \\
2 & 113210008 & 1.4021018590 .0039465531 .402102 & 0.003947 \\
3 & 43310027 & 1.5474945470 .0043557961 .547495 & 0.004356 \\
4 & 63310064 & 1.8111471290 .0050979091 .811147 & 0.005098 \\
5 & 93310007 & 1.8792570390 .0052896211 .879257 & 0.00529 \\
6 & 93310013 & 1.8337708160 .0051615891 .833771 & 0.005162 \\
7 & 103310025 & 1.8549011570 .0052210651 .854901 & 0.005221 \\
8 & 113310012 & 1.63425907 & 0.0046000151 .634259 & 0.0046 \\
9 & 113310014 & 2.3222564840 .0065365492 .322256 & 0.006537 \\
10 & 113310015 & 1.6160836720 .0045488561 .616084 & 0.004549 \\
11 & 113310019 & 2.1318281610 .0060005432 .131828 & 0.006001 \\
12 & 113310035 & 1.5873602950 .004468007 & 1.58736 & 0.004468 \\
13 & 103110113 & 2.1942608410 .0061762752 .194261 & 0.006176 \\
14 & 113110001 & 1.63459433 & 0.0046009591 .634594 & 0.004601 \\
15 & 113110004 & 1.3513418070 .0038036771 .351342 & 0.003804 \\
16 & 113110017 & 1.36254731 & 0.0038352171 .362547 & 0.003835 \\
17 & 113110048 & 2.2320936870 .0062827652 .232094 & 0.006283 \\
18 & 113110051 & 2.45163377 & 0.0069007132 .451634 & 0.006901 \\
19 & 113110056 & 1.6168562380 .0045510311 .616856 & 0.004551 \\
20 & 113110064 & 1.7938903610 .005049336 & 1.79389 & 0.005049 \\
21 & 113110065 & 1.5785508020 .0044432111 .578551 & 0.004443 \\
22 & 113110067 & 1.3445817490 .0037846491 .344582 & 0.003785 \\
23 & 113110090 & 2.448517005 & 0.006891942 .448517 & 0.006892 \\
24 & 113110091 & 1.9506427560 .0054905531 .950643 & 0.005491 \\
\hline & & & & \\
\hline
\end{tabular}

\begin{tabular}{|c|c|c|c|c|}
\hline \multirow{2}{*}{$\begin{array}{c}\text { Al- } \\
\text { ter } \\
\text { na- } \\
\text { tif }\end{array}$} & \multirow[t]{2}{*}{ No Mhs } & \multicolumn{2}{|c|}{$\begin{array}{c}\text { Hasil Perhitungan } \\
\text { Spreadsheet }\end{array}$} & $\begin{array}{c}\text { Hasil Perhitungan } \\
\text { Aplikasi }\end{array}$ \\
\hline & & tor $S$ & Vekt & lektor S Nilai V \\
\hline 98 & 95 & 13 & & 1.4 \\
\hline 99 & & & & \\
\hline $10 C$ & 854 & 2.4 & 21 & 2.4 \\
\hline 101 & & & & \\
\hline 102 & 854 & 8 & 07 & 80. \\
\hline $10 \equiv$ & & & & \\
\hline $10<$ & & 1.5 & & 1.5 \\
\hline 10 s & & & & \\
\hline $10 \epsilon$ & & & & \\
\hline 107 & & & & 1. \\
\hline $10 \varepsilon$ & & & & \\
\hline $10 s$ & & & & 1.5 \\
\hline $11 C$ & & & & \\
\hline 111 & 95 & & 54 & 1.7 \\
\hline 112 & 04 & 19 & & 2.0 \\
\hline $11 \equiv$ & & 2.0 & & 2.06 \\
\hline $11<$ & 95 & 1.6 & 0.0 & 1.62 \\
\hline 115 & & & & $1.73 \mathrm{~s}$ \\
\hline $11 \epsilon$ & & 2.12 & & 340.00597 \\
\hline 117 & & & & 640.00499 \\
\hline $11 \varepsilon$ & 247 & 1.604441 & 0.004516 & 1.6044410 .004516 \\
\hline $11 \subseteq$ & 95410298 & 1.944279 & 0.005473 & 1.9442790 .005473 \\
\hline $12 C$ & 105410007 & 1.362129 & 0.003834 & 1.3621290 .003834 \\
\hline 121 & 105410013 & 2.296637 & 0.006464 & 2.2966370 .006464 \\
\hline
\end{tabular}




\begin{tabular}{|c|c|c|c|c|}
\hline \multirow{2}{*}{$\begin{array}{c}\text { Al- } \\
\text { ter- } \\
n a- \\
\text { tif }\end{array}$} & \multirow{2}{*}{ No Mhs } & \multicolumn{2}{|c|}{$\begin{array}{l}\text { Hasil Perhitungan } \\
\text { Spreadsheet }\end{array}$} & \multirow{2}{*}{$\begin{array}{c}\begin{array}{c}\text { Hasil Perhitungan } \\
\text { Aplikasi }\end{array} \\
\text { Vektor S Vektor V }\end{array}$} \\
\hline & & Vektor S & Vektor V & \\
\hline
\end{tabular}

$\begin{array}{lllll}25 & 113110097 & 1.7773845380 .0050028761 .777385 & 0.005003\end{array}$ $\begin{array}{lllll}26 & 113110106 & 1.7711054290 .0049852021 .771105 & 0.004985\end{array}$ $\begin{array}{lllll}27 & 123110013 & 2.1493784250 .0060499432 .149378 & 0.00605\end{array}$ $\begin{array}{lllll}28 & 123110015 & 1.6726723170 .0047081391 .672672 & 0.004708\end{array}$ $\begin{array}{lllllll}29 & 35610050 & 1.74934051 & 0.00492394 & 1.749341 & 0.004924\end{array}$ $\begin{array}{lllll}30 & 75610039 & 1.5987462270 .0045000561 .598746 & 0.0045\end{array}$

$\begin{array}{llllll}31 & 85610112 & 1.4128058130 .003976682 & 1.412806 & 0.003977\end{array}$

$\begin{array}{lllllll}32 & 85610137 & 2.147988286 & 0.00604603 & 2.147988 & 0.006046\end{array}$

$\begin{array}{llllll}33 & 95610017 & 1.9650909360 .0055312211 .965091 & 0.005531\end{array}$

$\begin{array}{lllll}34 & 95610037 & 1.2828840380 .0036109861 .282884 & 0.003611\end{array}$

$\begin{array}{lllll}35 & 95610048 & 1.5649879310 .0044050351 .564988 & 0.004405\end{array}$

$\begin{array}{lllll}36 & 95610059 & 1.5002312110 .0042227621 .500231 & 0.004223\end{array}$

$\begin{array}{lllllll}37 & 95610066 & 1.25383241 & 0.0035292131 .253832 & 0.003529\end{array}$

$\begin{array}{lllll}38 & 95610069 & 1.9181080750 .0053989771 .918108 & 0.005399\end{array}$

$\begin{array}{llllll}39 & 95610083 & 1.2013781620 .0033815681 .201378 & 0.003382\end{array}$

$\begin{array}{llllll}40 & 95610094 & 1.3120004560 .003692941 & 1.312 & 0.003693\end{array}$

$\begin{array}{lllll}41 & 95610104 & 2.1429163670 .0060317542 .142916 & 0.006032\end{array}$

$\begin{array}{llllll}42 & 95610172 & 2.05542829 & 0.0057854972 .055428 & 0.005785\end{array}$

$\begin{array}{llllll}43 & 105610004 & 1.9668613420 .0055362041 .966861 & 0.005536\end{array}$

$\begin{array}{llllll}44 & 105610015 & 1.8270466460 .0051426621 .827047 & 0.005143\end{array}$

$\begin{array}{llllll}45 & 105610062 & 1.4579698160 .004103807 & 1.45797 & 0.004104\end{array}$

$\begin{array}{lllll}46 & 105610063 & 1.6917607870 .0047618681 .691761 & 0.004762\end{array}$

$\begin{array}{lllll}47 & 105610066 & 1.2915617390 .003635411 & 1.291562 & 0.003635\end{array}$

$\begin{array}{llllll}48 & 105610081 & 1.8499440230 .0052071121 .849944 & 0.005207\end{array}$

$\begin{array}{lllllll}49 & 105610083 & 2.0921700750 .005888916 & 2.09217 & 0.005889\end{array}$

$\begin{array}{lllll}50 & 105610090 & 1.5886932170 .0044717591 .588693 & 0.004472\end{array}$

$\begin{array}{lllll}51 & 105610091 & 1.7836833060 .0050206061 .783683 & 0.005021\end{array}$

$\begin{array}{lllll}52 & 105610093 & 1.5829678580 .0044556441 .582968 & 0.004456\end{array}$

$\begin{array}{llllll}53 & 105610097 & 1.3495225320 .0037985561 .349523 & 0.003799\end{array}$

$\begin{array}{llllll}54 & 105610100 & 2.0291304660 .005711476 & 2.02913 & 0.005711\end{array}$

$\begin{array}{lllll}55 & 105610101 & 1.9012975290 .0053516591 .901298 & 0.005352\end{array}$

$\begin{array}{llllll}56 & 105610102 & 2.15720338 & 0.0060719682 .157203 & 0.006072\end{array}$

$\begin{array}{lllll}57 & 105610104 & 2.2594510890 .0063597692 .259451 & 0.00636\end{array}$

$\begin{array}{lllll}58 & 105610108 & 1.6595061470 .004671079 & 1.659506 & 0.004671\end{array}$

$\begin{array}{lllll}59 & 105610109 & 2.0232792520 .0056950062 .023279 & 0.005695\end{array}$

$\begin{array}{lllll}60 & 105610121 & 1.8116877760 .0050994311 .811688 & 0.005099\end{array}$

$\begin{array}{lllll}61 & 105610132 & 1.5143236230 .004262428 & 1.514324 & 0.004262\end{array}$

$\begin{array}{lllll}62 & 105610142 & 1.8365225990 .0051693351 .836523 & 0.005169\end{array}$

$\begin{array}{lllll}63 & 105610147 & 1.6435757120 .0046262391 .643576 & 0.004626\end{array}$

$\begin{array}{llllll}64 & 105610148 & 1.4712589780 .0041412121 .471259 & 0.004141\end{array}$

$\begin{array}{lllll}65 & 105610150 & 2.2609639240 .0063640272 .260964 & 0.006364\end{array}$

$\begin{array}{lllllll}66 & 115610007 & 1.857787636 & 0.00522919 & 1.857788 & 0.005229\end{array}$

$\begin{array}{llllll}67 & 115610017 & 2.1086853150 .0059354022 .108685 & 0.005935\end{array}$

$\begin{array}{lllll}68 & 115610020 & 2.1454046270 .0060387572 .145405 & 0.006039\end{array}$

$\begin{array}{llllll}69 & 115610023 & 1.67112778 & 0.0047037911 .671128 & 0.004704\end{array}$

$\begin{array}{lllll}70 & 115610025 & 1.7768005670 .0050012331 .776801 & 0.005001\end{array}$

$\begin{array}{lllll}71 & 115610026 & 1.9240046140 .0054155741 .924005 & 0.005416\end{array}$

$\begin{array}{lllll}72 & 115610028 & 2.5034440990 .0070465462 .503444 & 0.007047\end{array}$

$\begin{array}{lllll}73 & 115610032 & 1.4366928060 .0040439171 .436693 & 0.004044\end{array}$

$\begin{array}{lllll}74 & 115610042 & 1.8800671530 .0052919011 .880067 & 0.005292\end{array}$

$\begin{array}{llllll}75 & 115610051 & 1.3521439750 .0038059341 .352144 & 0.003806\end{array}$

$\begin{array}{llllll}76 & 115610053 & 1.3975921 & 0.0039338591 .397592 & 0.003934\end{array}$

$\begin{array}{llllll}77 & 115610055 & 1.9239982 & 0.0054155561 .923998 & 0.005416\end{array}$

$\begin{array}{llllll}78 & 115610069 & 2.5524793530 .0071845672 .552479 & 0.007185\end{array}$

$\begin{array}{llllll}79 & 115610090 & 2.5737738450 .0072445062 .573774 & 0.007245\end{array}$

$\begin{array}{lllll}80 & 115610114 & 1.6002234530 .0045042141 .600223 & 0.004504\end{array}$

$\begin{array}{llllll}81 & 115610116 & 1.3736067640 .0038663471 .373607 & 0.003866\end{array}$

$\begin{array}{lllll}82 & 115610120 & 1.7953890130 .0050535541 .795389 & 0.005054\end{array}$

$\begin{array}{lllllll}83 & 125610023 & 1.4033597860 .003950094 & 1.40336 & 0.00395\end{array}$

$\begin{array}{lllll}84 & 125610172 & 1.5909872280 .0044782161 .590987 & 0.004478\end{array}$

$\begin{array}{llllll}85 & 125610202 & 1.8763468010 .005281429 & 1.876347 & 0.005281\end{array}$

$\begin{array}{lllll}86 & 135610137 & 1.9300721360 .0054326521 .930072 & 0.005433\end{array}$

$\begin{array}{llllll}87 & 135610138 & 1.4134073150 .003978375 & 1.413407 & 0.003978\end{array}$

$\begin{array}{lllll}88 & 135610149 & 1.6265418390 .0045782931 .626542 & 0.004578\end{array}$

$\begin{array}{lllll}89 & 135610155 & 1.6693137850 .0046986851 .669314 & 0.004699\end{array}$

$\begin{array}{lllll}90 & 135610158 & 2.0503420150 .0057711812 .050342 & 0.005771\end{array}$

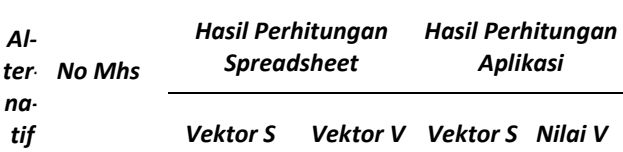

\begin{tabular}{llll}
\hline 122105410017 & 1.793201 & 0.005047 & 1.7932010 .005047
\end{tabular}

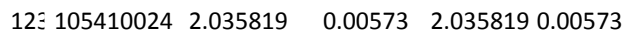
$\begin{array}{lllll}12< & 105410027 & 1.797781 & 0.00506 & 1.7977810 .00506\end{array}$ $\begin{array}{llllll}125 & 105410034 & 1.54235 & 0.004341 & 1.54235 & 0.004341\end{array}$ $\begin{array}{lllll}12 \epsilon & 105410057 & 2.450536 & 0.006898 & 2.4505360 .006898\end{array}$ $\begin{array}{lllll}12 i & 105410061 & 2.137683 & 0.006017 & 2.1376830 .006017\end{array}$

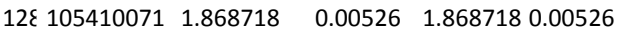

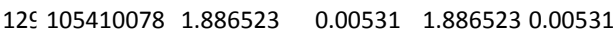
13C $\begin{array}{llll}105410081 & 1.606192 & 0.004521 & 1.6061920 .004521\end{array}$ 131 $105410092 \quad 2.178522 \quad 0.006132 \quad 2.1785220 .006132$ $\begin{array}{lllll}132 & 105410104 & 2.309637 & 0.006501 & 2.3096370 .006501\end{array}$ $\begin{array}{lllll}13 & 105410105 & 1.915556 & 0.005392 & 1.9155560 .005392\end{array}$

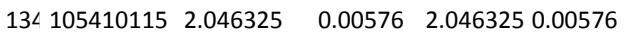
$\begin{array}{lllll}13 & 105410121 & 2.224586 & 0.006262 & 2.2245860 .006262\end{array}$

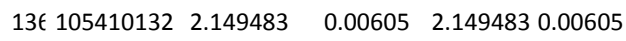
$\begin{array}{lllll}137 & 105410133 & 1.814272 & 0.005107 & 1.8142720 .005107\end{array}$ $\begin{array}{lllll}138 & 105410145 & 2.169039 & 0.006105 & 2.1690390 .006105\end{array}$

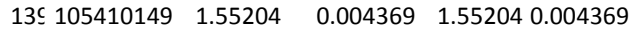
14C $105410152 \quad 2.037616 \quad 0.005735 \quad 2.0376160 .005735$ $\begin{array}{lllll}141 & 105410155 & 1.950007 & 0.005489 & 1.9500070 .005489\end{array}$ $\begin{array}{llllll}14 \approx & 105410211 & 2.229059 & 0.006274 & 2.2290590 .006274\end{array}$ $14 \equiv \begin{array}{llll}105410220 & 1.365533 & 0.003844 & 1.3655330 .003844\end{array}$ $\begin{array}{llllll}14<105410223 & 1.90943 & 0.005375 & 1.90943 & 0.005375\end{array}$ 14巨 $105410229 \quad 1.286093 \quad 0.00362 \quad 1.2860930 .00362$ 14€ $105410241 \quad 1.600855 \quad 0.004506 \quad 1.6008550 .004506$

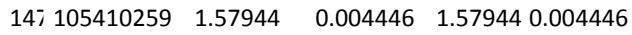

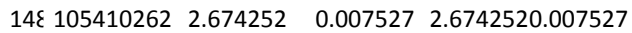
$\begin{array}{lllll}14 \mathrm{C} & 105410268 & 1.750968 & 0.004929 & 1.7509680 .004929\end{array}$ 15C $105410282 \quad 2.264129 \quad 0.006373 \quad 2.2641290 .006373$ $\begin{array}{lllll}151 & 105410293 & 2.07499 & 0.005841 & 2.07499 \\ 0.005841\end{array}$ $\begin{array}{lllll}152 & 105410319 & 2.094319 & 0.005895 & 2.0943190 .005895\end{array}$ $\begin{array}{lllll}15 & 105410345 & 1.909769 & 0.005376 & 1.9097690 .005376\end{array}$ $\begin{array}{lllll}15<105410348 & 1.991891 & 0.005607 & 1.9918910 .005607\end{array}$ $\begin{array}{lllll}15 & 113110039 & 1.780684 & 0.005012 & 1.7806840 .005012\end{array}$ $\begin{array}{lllll}15 € & 115410001 & 2.262894 & 0.006369 & 2.2628940 .006369\end{array}$ $\begin{array}{lllll}15 & 115410008 & 1.564271 & 0.004403 & 1.5642710 .004403\end{array}$ $\begin{array}{lllll}15 \& 115410013 & 1.955329 & 0.005504 & 1.9553290 .005504\end{array}$ $\begin{array}{lllll}15 \subseteq 115410025 & 2.031781 & 0.005719 & 2.0317810 .005719\end{array}$ $\begin{array}{lllll}16 \mathrm{C} & 115410032 & 2.048808 & 0.005767 & 2.0488080 .005767\end{array}$ $\begin{array}{llllll}161 & 115410033 & 2.279322 & 0.006416 & 2.2793220 .006416\end{array}$ $\begin{array}{lllll}162 & 115410037 & 1.610999 & 0.004535 & 1.6109990 .004535\end{array}$ $\begin{array}{lllll}16 ミ 115410041 & 1.928273 & 0.005428 & 1.9282730 .005428\end{array}$ $\begin{array}{llllll}16<115410045 & 1.77506 & 0.004996 & 1.77506 & 0.004996\end{array}$ $\begin{array}{lllll}16 & 115410057 & 1.705612 & 0.004801 & 1.7056120 .004801\end{array}$ $\begin{array}{lllll}16 \in & 115410059 & 2.023312 & 0.005695 & 2.0233120 .005695\end{array}$

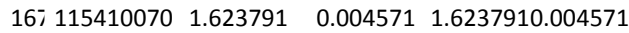
$\begin{array}{lllll}16 \varepsilon & 115410072 & 1.758765 & 0.00495 & 1.7587650 .00495\end{array}$ $\begin{array}{lllll}16 \subseteq & 115410086 & 2.135522 & 0.006011 & 2.1355220 .006011\end{array}$ 17C $1154100892.154526 \quad 0.006064 \quad 2.1545260 .006064$ $\begin{array}{lllll}171 & 115410099 & 2.154846 & 0.006065 & 2.1548460 .006065\end{array}$ $\begin{array}{lllll}17 & 115410103 & 1.619089 & 0.004557 & 1.6190890 .004557\end{array}$ $17 \geqq \begin{array}{lllll}115410112 & 1.384428 & 0.003897 & 1.3844280 .003897\end{array}$ $\begin{array}{lllll}17 \angle & 115410115 & 1.919561 & 0.005403 & 1.9195610 .005403\end{array}$ $\begin{array}{lllll}17 \text { 드 } 115410149 & 2.593982 & 0.007301 & 2.5939820 .007301\end{array}$

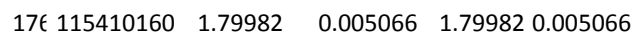
$\begin{array}{lllll}171 & 115410164 & 1.433972 & 0.004036 & 1.4339720 .004036\end{array}$

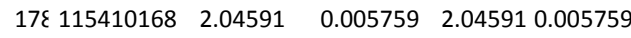
$\begin{array}{lllll}17 \subseteq & 115410171 & 2.200479 & 0.006194 & 2.2004790 .006194\end{array}$ $\begin{array}{lllll}18 \mathrm{C} & 115410182 & 2.194723 & 0.006178 & 2.1947230 .006178\end{array}$ $\begin{array}{lllll}181 & 115410213 & 2.052793 & 0.005778 & 2.0527930 .005778\end{array}$ $\begin{array}{llllll}182 & 115410214 & 2.127735 & 0.005989 & 2.1277350 .005989\end{array}$ $\begin{array}{lllll}18 & 115410215 & 2.207806 & 0.006214 & 2.2078060 .006214\end{array}$ $\begin{array}{lllll}18<115410224 & 2.050367 & 0.005771 & 2.0503670 .005771\end{array}$ $\begin{array}{llllll}18 & 115410228 & 1.709083 & 0.004811 & 1.7090830 .004811\end{array}$ $\begin{array}{llllll}18 € & 115410265 & 1.408401 & 0.003964 & 1.4084010 .003964\end{array}$

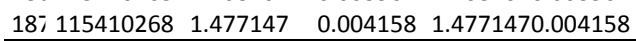




\begin{tabular}{|c|c|c|c|c|c|}
\hline \multirow{2}{*}{$\begin{array}{c}\text { Al- } \\
\text { ter- } \\
\text { na- } \\
\text { tif }\end{array}$} & \multirow[t]{2}{*}{ No Mhs } & \multicolumn{2}{|c|}{$\begin{array}{c}\text { Hasil Perhitungan } \\
\text { Spreadsheet }\end{array}$} & \multicolumn{2}{|c|}{$\begin{array}{c}\text { Hasil Perhitungan } \\
\text { Aplikasi } \\
\end{array}$} \\
\hline & & Vektor S & Vektor V & Vektor S & Vektor V \\
\hline 92 & 135610178 & 1.308796207 & 0.003683922 & 1.308796 & 0.003684 \\
\hline 93 & 15410067 & 1.911075323 & 0.005379181 & 1.911075 & 0.005379 \\
\hline 94 & 25410322 & 2.032424829 & 0.005720749 & 2.032425 & 0.005721 \\
\hline 95 & 45410118 & 1.388925472 & 0.003909465 & 1.388925 & 0.003909 \\
\hline 96 & 55410238 & 1.632779271 & 0.00459585 & 1.632779 & 0.004596 \\
\hline 97 & 65410072 & 1.598919929 & 0.004500545 & 1.59892 & 0.004501 \\
\hline
\end{tabular}

\begin{tabular}{|c|c|c|c|}
\hline \multirow[t]{2}{*}{ No Mhs } & \multicolumn{2}{|c|}{$\begin{array}{c}\text { Hasil Perhitungan } \\
\text { Spreadsheet }\end{array}$} & \multirow{2}{*}{$\begin{array}{c}\begin{array}{c}\text { Hasil Perhitungan } \\
\text { Aplikasi }\end{array} \\
\text { Vektor S Vektor V }\end{array}$} \\
\hline & Vektor S & Vektor V & \\
\hline $18 \leq 125$ & 1.733346 & 0.00 & 460.004879 \\
\hline $19 \mathrm{C} 125$ & 2.407321 & 0.0 & 2.40 \\
\hline 19112 & & & \\
\hline $19=125$ & 2.202504 & 0.00 & 2.2025 \\
\hline $19 \equiv 125410285$ & 2.11 & 6 & 2.117 \\
\hline \multirow[t]{2}{*}{$19<125410322$} & 1.688933 & 0.004754 & 1.6889330 .004754 \\
\hline & 355.2725 & & 355.2725 \\
\hline
\end{tabular}

Tabel 4. memperlihatkan hasil perhitungan vektor S dan vektor V atas 194 alternatif, baik yang dilakukan menggunakan aplikasi web maupun menggunakan aplikasi spreadsheet. Dari hasil di atas terlihat kesesuaian antara perhitungan aplikasi web dan aplikasi spreadsheet mencapai 5 digit dibelakang koma. Hal ini dapat diterima mengingat adanya keterbatasan tipe variabel integer dalam bahasa php yang tidak cukup baik dalam menampung bilangan berpresisi tinggi hingga belasan digit di belakang koma.

Namun demikian setidaknya muncul 2 masalah dari kondisi di atas yang saling berkontradiksi. Pertama, apabila tingkat presisi bilangan tidak terlalu tinggi maka hal tersebut tentu akan menguntungkan dari sisi sumberdaya karena tidak akan diperlukan prosessor dan memori server yang terlalu besar namun juga merugikan karena akan memungkinkan terjadinya perbedaan hasil perangkingan apabila jarak nilai $\mathrm{V}$ antara alternatifalternatif yang ada sangat sempit. Kedua. berlaku sebaliknya, yaitu apabila tingkat presisi bilangan sangat tinggi maka hal tersebut tentu akan menguntungkan dari sisi hasil perangkingan karena akan memberikan hasil berupa jarak nilai $\mathrm{V}$ antara alternatif-alternatif akan menjadi lebar, namun kerugiannya adalah dari sisi sumberdaya pasti akan diperlukan prosessor dan memori server yang cukup besar. Dalam penelitian ini upaya untuk meningkatkan tingkat ketelitian presisi terhadap bilangan-bilangan tersebut belum dapat dilakukan karena memerlukan kajian lebih lanjut.

Meskipun tingkat ketelitian perhitungan antara aplikasi web yang dibangun dengan aplikasi spreadsheet hanya mampu mencapai 5 digit di belakang koma namun hasil perangkingan alternatif tidak memberikan hasil yang berbeda karena data uji yang digunakan [5] masih memungkinkan untuk keterbatasan yang dimaksud.

Gambar 5 memperlihatkan cuplikan hasil perangkingan atas alternatif berdasarkan nilai V secara urut turun (descending). Hasil urutan alternatif inilah yang kemudian menjadi hasil dari aplikasi mesin pencari dalam menemukan lulusan yang memiliki kompetensi sesuai dengan kriteria yang ditetapkan pengguna lulusan.

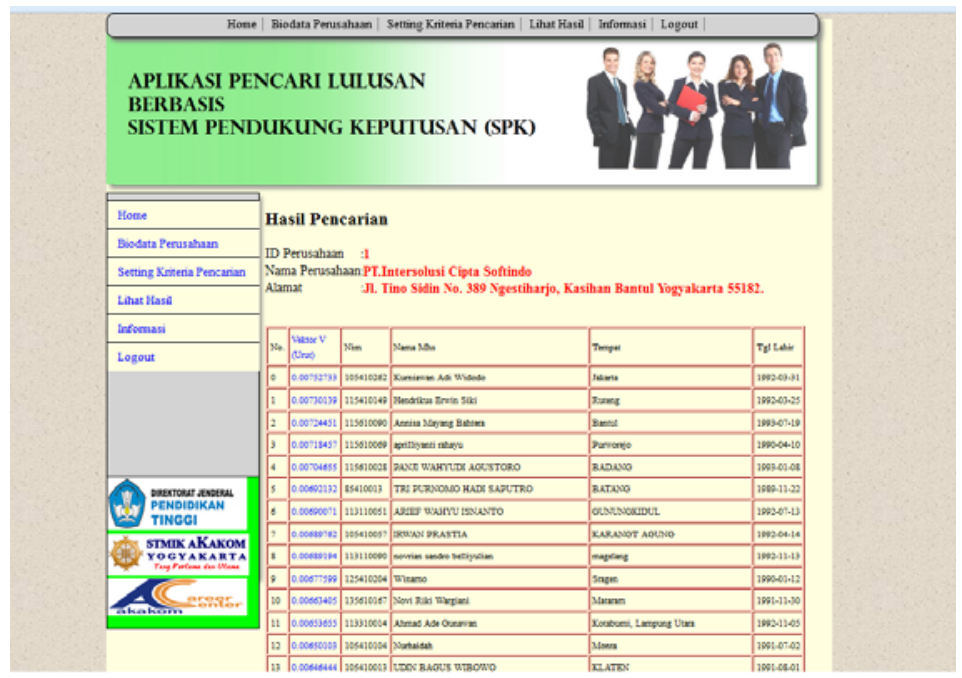

\section{Gambar 5. Output Aplikasi Berupa Hasil Perangkingan Atas Alternatif Berdasarkan Nilai V}

\section{SIMPULAN}

Dari hasil penelitian ini dapat disimpulkan beberapa hal sebagai berikut :

1) WP dapat digunakan sebagai metode pengurutan kriteria calon tenaga kerja dan dapat diterapkan dalam mesin pencari data lulusan.

2) Berdasarkan data lulusan yang digunakan, aplikasi mampu melakukan pengurutan data lulusan (alternatif) hingga 194 lulusan berdasarkan 13 kriteria dan 55 sub kriteria yang ditentukan oleh pengguna lulusan. 
3) Telah dilakukan uji komparasi antara aplikasi yang dibangun dengan aplikasi speadsheet yang menghasilkan tingkat presisi bilangan mencapai 5 digit di belakang koma, namun tidak memberikan perbedaan atas hasil perangkingannya.

4) Berkaitan dengan tingkat presisi bilangan atas hasil perhitungan aplikasi muncul 2 dilema antara harus meningkatkan presisi bilangan atau tetap menggunakan bilangan berpresisi rendah dengan semua konsekuensinya.

\section{DAFTAR PUSTAKA}

[1] Syafiq, A. 2008. "Link And Match, Solusi Atau Ilusi?" URL : http://materi.uniku.ac.id/tracer\%20studi\%20dikti/link\%20and\%20match.html, diakses tanggal 22 Januari 2013.

[2] Prasetyo, AB. 2016. “Analytical Hierarchy Proccess (AHP) Untuk Membangun Mesin Pencari Data Lulusan Perguruan Tinggi Berdasarkan Kebutuhan Pengguna Lulusan”. Jurnal Simetris Volume 7 No 1 Tahun 2016.

[3] Kusumadewi, S., et al. 2006. A. Fuzzy Multi -Attribute Decision Making. Yogyakarta : Graha Ilmu.

[4] Peranginangin K. 2006. "Aplikasi WEB dengan PHP dan MySQL". Andi Offset, Yogyakarta.

[5] Prasetyo, AB. 2015. "Laporan Program Tracer Study STMIK AKAKOM 2015, STMIK AKAKOM, Yogyakarta 